\title{
Nuclear Matrix Protein
}

National Cancer Institute

\section{Source}

National Cancer Institute. Nuclear Matrix Protein. NCI Thesaurus. Code C17517.

Proteins that give shape to the nucleus and provide support for the chromosomes. 